Ann. Rept. Kansai PI. Prot. (56): 1-5 (2014)

\title{
異なる植物上でのタイリクヒメハナカメムシの生存と ソバの花での発育，産卵
}

\author{
太田 泉・武田光能 \\ Izumi Ohta and Mitsuyoshi Takeda: Adult survival of Orius strigicollis (Poppius) \\ on different flowering plants and its development and fecundity on buckwheat flowers
}

\section{Summary}

In conservation biological control programs, cultivation of flowering plants around/in agricultural fields is considered to be an effective approach to enhance predatory activity of natural enemies by providing their foods, refuges and oviposition sites. The minute pirate bug, Orius strigicollis, is an omnivorous predator and is used as an important biological control agent against thrips pests in Japan. However, little is known about the insectary plants available for $O$. strigicollis. Here, we investigated the longevity of $O$. strigicollis adults maintained on flowers and leaves of 10 plant species. In all tested plants except for French marigold, the predators fed on flowers survived longer than those fed on leaves of the same plants. In particular, flowers of buckwheat, coriander, dill, fairy-fan flower, holly basil, sweet alyssum and vervain increased longevity of $O$. strigicollis by four fold or more than the corresponding leaves. However, survival rate of $O$. strigicollis nymphs and the number of eggs deposited by female adults on buckwheat flowers was lower than those fed on Mediterranean flour moth eggs. Based on these results, we discussed possibilities of flowering plants serving as food resources for $O$. strigicollis in the field.

\section{緒 言}

タイリクヒメハナカメムシ Orius strigicollis (Poppius) (カメムシ目：ハナカメムシ科）は，2001年にアザミウ マ類の生物的防除資材として農薬登録され，おもにナス やピーマンなどの果菜類で使用されている (Hinomoto et al., 2009)．生物農薬としての本種の利用は，2013年 6 月現在, ビニールハウスなどの施設ほ場に限られてい るが，日本国内（南西諸島を除く）には本種を含めて 4 種のコヒメハナカメムシ亜属 (Heterorius) のヒメハナ カメムシ類が生息しているため（安永, 2001）, これら 野外個体群を露地ほ場内に定着させて利用する方法も検 討されている（井村・神川, 2012).

大野（2012）は，露地ほ場における土着天敵の利用法 の一つとして, 餌の供給源や隠れ場所となる “天敵温存 植物 (Insectary plant)”を湯の中やその周辺に配置し て, 天敵の生存率や寿命, 産卵数, 移動能力を向上さ せる取り組みを挙げている。また，捕食性の天敵昆虫 に各種植物の花粉などを与えた場合の発育や生存, 増 殖に与える影響を調査した報告もあるが（Eubanks and
Styrsky，2005），日本国内に生息するヒメハナカメムシ 類に関するこの側面からの研究事例は少ない. そこで, 本研究では，過去に寄生蜂などの天敵温存植物候補とし て取り扱われたことのある植物を中心に10種を選定し， それらを本種成虫に与えて生存期間を比較し，タイリク ヒメハナカメムシの餌資源としての評価を行った. また, 成虫に対する延命効果が高かった植物の一つのソバの花 については, タイリクヒメハナカメムシ幼虫および䧳成 虫に餌として与えた場合の発育期間や生存率，産卵数も 調べた。

本研究は，新たな農林水産政策を推進する実用技術開 発事業「西南暖地の果菜類における農業に有用な生物多 様性の管理技術の確立」（2009～2011年度）において得 られた成果の一部である.

\section{材料および方法}

\section{1。供試虫}

タイリクヒメハナカメムシは, アリスタライフサイエ ンス株式会社からタイリクヒメハナカメムシ剂（商品

（独）農業・食品産業技術総合研究機構野菜茶業研究所 NARO Institute of Vegetable and Tea Science 2014年 1 月 5 日受理 
名：タイリク $\left.{ }^{\circledR}\right)$ を購入し，慨としてスジコナマラダメ イガ冷凍卵（住化テクノサービス株式会社），産卵基質 として根の部分を水で湿らせたペーパータオルとアルミ ホイルで包んだダイズ子葉（品種：ふくゆたか）を与え て, 温度約 $20^{\circ} \mathrm{C}$, 日長 $14 \mathrm{~L}-10 \mathrm{D}$ に調整した恒温室で継 代飼育した。飭と産卵基質は 2,3 日間隔で交換した。

\section{2. 供試植物}

コリアンダーCoriandrum sativum R.Br., シロツメ クサ Trifolium repens $\mathrm{L} .($ 品種 : フィア)，スィートア リッサムLobularia maritima（L.）Desv.（品種：スノー ドリフト), スカエボラ Scaevola aemula R.Br., ソバ Fagopyrum esculentum Moench（品種：信州大そば), ディ ル Anethum graveolens L., バーベナ Verbena $\times$ hybrida（品 種 : タピアン), ハゼリソウ Phacelia tanacetifolia Benth. (品種 : アンジェリア)，フレンチマリーゴールド Tagetes patula L.（品種：ボナンザイエロー)，ホーリーバジル Ocimum tenuiflorum L.の10種を供試した. 各植物の種子 をプランター（内寸 $58 \times 19 \mathrm{~cm}$, 深さ $18 \mathrm{~cm}$ ）に播種し, ガラス温室（11〜 3 月は加温により最低温度を $18^{\circ} \mathrm{C}$ 以 上に維持し, それ以外は温度制御なし）の中で育成した。 なお，スカエボラとバーベナは苗の状態で入手し，プラ ンターに植えてから 2 ヶ月以上育成したものを試験に用 いた。

\section{3. 各種植物の花と葉におけるタイリクヒメハナカメム シ雌成虫の生存期間}

それぞれの供試植物から花もしくは葉を茎や葉柄が付 いた状態でそれぞれ $1 \sim 3$ 本切除し, スポンジ $(8 \times 2 \mathrm{~cm}$, 厚さ $1.5 \mathrm{~cm}$ ）を巻き付けた後に水を満たした $50 \mathrm{ml}$ 三角 フラスコに差し込んだ。直径 $9.5 \mathrm{~cm}$, 高さ $16 \mathrm{~cm}$ の透明 プラスチック円筒容器の中に供試植物と羽化後 2 日以内 のタイリクヒメハナカメムシ雌成虫 1 頭（交尾は確認し ていないが，供試前まで他個体と集団飼育）を置き，温 度約 $22^{\circ} \mathrm{C}$, 日長 $14 \mathrm{~L}-10 \mathrm{D}$ の条件下で飼育した。以後, 供試虫が死亡するまで毎日観察し，各個体の生存期間を 明らかにした．また，対照として，25\%蜂蜜水溶液を与 えた場合と，餌や水を与えなかった場合の生存期間も調 べた。 $25 \%$ 蜂蜜水溶液は, 同液を満たした $50 \mathrm{ml}$ 三角フ ラスコにロール状に巻いたペーパータオル $($ 長さ約 $10 \mathrm{~cm}$, 直径約 $1.5 \mathrm{~cm}$ ）を挿入したものを透明プラスチック円筒 容器内に入れて給餌した。餌の植物は 1 週間間隔，蜂蜜 水溶液は 3 日間隔で交換した。 1 つの試験につき 12 頭の タイリクヒメハナカメムシを供試し, 試験途中で紛失し た個体はデータから除外した。
4. ソバの花におけるタイリクヒメハナカメムシ幼虫の 発育

前項と同じ方法で，タイリクヒメハナカメムシ幼虫に ソバの花を与えて, 飼育試験を行った. 継代飼育中の個 体群から孵化後 1 日以内のタイリクヒメハナカメムシ 1 齢幼虫を取り出し, 餌としてソバの花（葉 1 枚が付い た状態のもの） 2 本を与えて, 温度約 $22^{\circ} \mathrm{C}$, 日長 $14 \mathrm{~L}-$ $10 \mathrm{D}$ の条件下で個体別に飼育した.ソバの花は 3 日間隔 で取り替えた。供試虫が死亡もしくは成虫に羽化するま で毎日観察し，生存率（成虫まで羽化した個体の割合） と発育所要日数（成虫まで羽化するのに要した時間）を 明らかにした。 また, 羽化成虫は個体別にサンプル瓶に 入れて保存し, 死亡後に実体顕微鏡下で雌雄と後脚脛節 長を記録した. なお, 試験の途中で幼虫を 3 日間発見で きなかった場合は，その飼育容器内の個体は死亡したと みなした。

対照として, ヒメハナカメムシ類の継代飼育や大量増 殖に利用されているスジコナマダラメイガ冷凍卵を餌と して与えた場合の発育も調べた. $2 \mathrm{~cm}$ 四方に切り取っ た濾紙の中央に, 長さ $2 \mathrm{~cm}$, 幅 $1 \mathrm{~cm}$ の両面テープを貼 り付けた後, テープ上にスジコナマダラメイガ卵を均一 に振りかけて卵カードを作った。 ソバの葉に卵カード 1 枚をホチキスで貼り付けたものをタイリクヒメハナカメ ムシ 1 齢幼虫に与えて飼育した。 供試したタイリクヒメ ハナカメムシ幼虫の頭数は, 餌がソバの花では 42 頭, ス ジコナマダラメイガ卵の場合は24頭だった。また，発育 期間や後脚脛節長を測定した羽化成虫個体数は，ソバの 花で雌12頭，雄11頭，スジコナマダラメイガ卵の場合は 䧳10頭, 雄11頭だった。

\section{5. ソバの花におけるタイリクヒメハナカメムシ雌成虫} の産卵

継代飼育中の個体群から羽化後 1 日以内のタイリクヒ メハナカメムシ成虫を取り出し, 前述と同じ飼育容器に 雌雄 1 ペアを入れて, 温度約 $22^{\circ} \mathrm{C}$, 日長 $14 \mathrm{~L}-10 \mathrm{D}$ の条 件下で飼育した。成虫には, 幼虫の飼育試験と同じソバ の花（葉 1 枚が付いた状態のもの）もしくはスジコナマ ダラメイガ卵を付けたソバの葉を䬶として与えて，3 日 間隔で新しいものと取り替えた。雄成虫は試験開始から 3 日目に取り除き，以後，ソバに産卵されたタイリクヒ メハナカメムシ卵を 3 日間隔で数えた。飼育は 15 日間 行った。なお, 試験開始から 6 日目（産卵数調査 2 回目） までに産卵が認められなかった雌成虫は, 雄成虫と交尾 しなかったとして本飼育試験から除外した。供試した夕 イリクヒメハナカメムシ雌成虫の頭数は, 飭がソバの花 の場合に 9 頭, スジコナマダラメイガ卵では11頭だった. 


\section{統 計解析}

各種植物におけるタイリクヒメハナカメムシ雌成虫の 生存期間を調べた試験では, 各データの分散が大きく異 なるため, 個体ごとの生存期間 $x$ を $\log (x+0.5)$ に変換 した後, Tukey-Kramerの多重比較によって有意差検定 を行った，タイリクヒメハナカメムシ幼虫の発育を調べ た試験では, 餌としてソバの花とスジコナマダラメイガ 卵を与えた場合の生存率はフィッシャーの正確確率検 定，発育期間と羽化した成虫の後脚脛節長は $t$ 検定（分 散が等しいと仮定できない場合は Welch の $t$ 検定）で比 較した。タイリクヒメハナカメムシ雌成虫の産卵数は, 調查を行った15日間の総産卵数について, 飭としてソ バの花とスジコナマダラメイガ卵を与えた場合の間で Welch の $t$ 検定により比較した.

\section{結果}

\section{1. 各種植物の花と葉におけるタイリクヒメハナカメム} シ雌成虫の生存期間

タイリクヒメハナカメムシ雌成虫の生存期間は，コリ アンダー (Coriander) の花で $44.1 \pm 20.5$ 日, 葉で $8.8 \pm 3.3$ 日 (平均土標準偏差, 以下同様), シロツメクサ（White clover）の花で $18.5 \pm 9.5$ 日，葉で6.5 22.5 日，スィート アリッサム（Sweet alyssum）の花で50.2 \pm 21.7 日，葉で

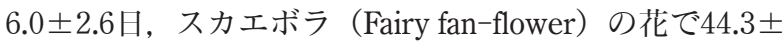

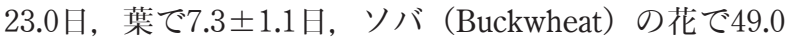
\pm 22.6 日, 葉で $8.3 \pm 1.7$ 日, ディル (Dill) の花で $39.8 \pm 7.9$ 日，葉で6.9 2.6 日，バーベナ (Vervain) の花で $41.1 \pm$ 15.0日，葉で9.6 \pm 2.6 日，ハゼリソウ（Lacy phacelia）の 花で $13.0 \pm 7.2$ 日，葉で $6.5 \pm 4.5$ 日，フレンチマリーゴー ルド（French marigold）の花で $8.6 \pm 2.2$ 日，葉で $6.0 \pm 2.1$ 日，ホーリーバジル（Holly basil）の花で39.4 21.9 日，

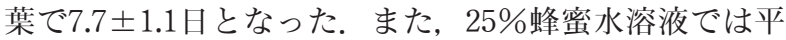

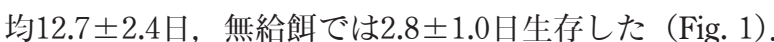
供試した各種植物のうちフレンチマリーゴールドを除く 9 種類では，花を与えられたタイリクヒメハナカメムシ 雌成虫個体が同植物の葉を与えられた個体と比べて有意 に長く生存できた $(p<0.05$, Tukey-Kramer の多重比較). 特に，コリアンダー，スィートアリッサム，スカエボラ， ソバ，ディル，バーベナ，ホーリーバジルの花を与えら れた個体は，同植物の葉を与えられた個体よりも 4 倍以 上長く生存し，シロツメクサ，八ゼリソウ，フレンチマ リーゴールドの花を与えられた個体と比較しても有意に 長く生存できた。一方，シロツメクサ，ハゼリソウ，フ レンチマリーゴールドの花を与えられたタイリクヒメハ ナカメムシ雌成虫の生存期間は，25\%蜂蜜水溶液を与元

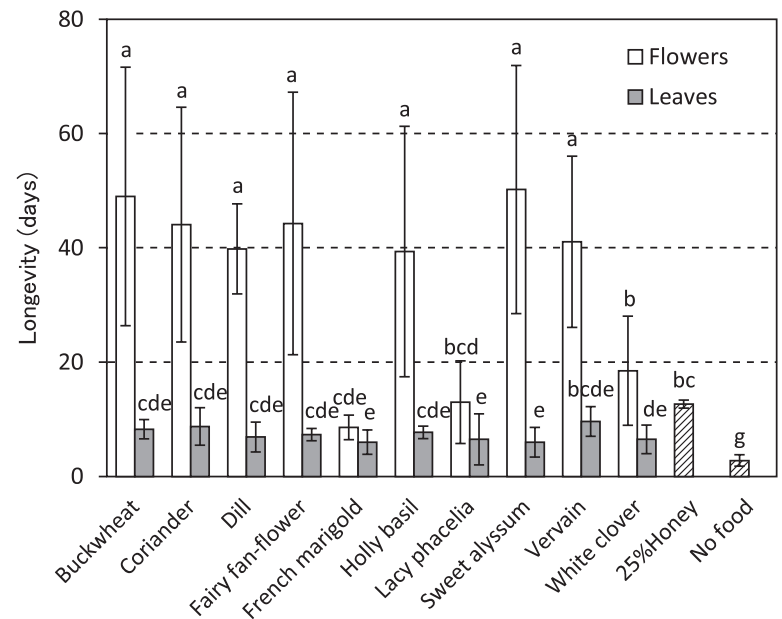

Fig. 1. Longevity of Orius strigicollis female adults maintained on plant flowers, leaves, $25 \%$ honey solution and no food. Bars and vertical lines indicate means and standard deviation, respectively. The longevities with the same alphabetic letters were not significantly different $(p>0.05$, Tukey-Kramer test after $\log (x+0.5)$ transformation).

られた場合と比較して有意な差は認められなかった（ $p$ $<0.05$, Tukey-Kramer の多重比較).

2. ソバの花におけるタイリクヒメハナカメムシ幼虫の 発育

ソバの花を与えられたタイリクヒメハナカメムシ幼虫 の生存率は, スジコナマダラメイガ卵を与えられた個体 の生存率よりも有意呧低かった $(p<0.05$, フィッシャー の正確確率検定)。成虫まで発育できた個体の発育期間 も，ソバの花を与えられた個体がスジコナマダラメイ ガ卵を与えられた個体よりも有意に長かった $(p<0.05$, Welch $t$ 検定).ささらに, 成虫の体サイズを示す後脚 脛節長も，ソバの花を与えられた個体で有意に小さかっ た $(p<0.05, t$ 検定) (Table 1).

3. ソバの花におけるタイリクヒメハナカメムシ雌成虫 の産卵

供試後15日間のタイリクヒメハナカメムシ雌成虫の産 卵数の推移を Fig. 2に示した. 䬲としてソバの花を与え られた個体の産卵数はスジコナマダラメイガ卵を与えら れた個体よりも少なく，15日間の雌成虫 1 頭当たりの総 産卵数も, ソバの花で19.8 111.1 個 (平均土標準偏差), スジコナマダラメイガ卵で $85.7 \pm 33.1$ 個となり，有意な 差が認められた $(p<0.05$, Welch $の t$ 検定).

\section{考察}

植物の花の多くは花粉や蜜を生産し，それらは様々な 昆虫の慨資源として利用されている（Wäckers and van 
Table 1. Effect of food source on survival and development of Orius strigicollis nymphs

\begin{tabular}{|c|c|c|c|c|c|}
\hline \multirow{2}{*}{ Food source } & \multirow{2}{*}{ Survival rate $(\%)^{\mathrm{a}}$} & \multicolumn{2}{|c|}{ Duration of development (days, mean $\pm \mathrm{SD}$ ) } & \multicolumn{2}{|c|}{ Length of adult hind tibia $(\mathrm{mm}$, mean $\pm \mathrm{SD}$ ) } \\
\hline & & Female & Male & Female & Male \\
\hline Buckwheat flowers & $54.8(42)$ & $16.8 \pm 2.5(12)$ & $16.6 \pm 2.7(11)$ & $0.605 \pm 0.010(12)$ & $0.599 \pm 0.009(11)$ \\
\hline Mediterranean flour moth eggs & $87.5(24)$ & $14.0 \pm 1.1(10)$ & $14.0 \pm 0.8(11)$ & $0.659 \pm 0.009(10)$ & $0.647 \pm 0.016(11)$ \\
\hline$P$-value & 0.006 & 0.003 & 0.008 & 0.001 & 0.016 \\
\hline
\end{tabular}

${ }^{a}$ Survival from first instar to adult emergence. Figures in parentheses indicate the numbers of insects tested. A $p$-value was calculated by Fisher's exact provability test.

${ }^{\mathrm{b}}$ Figures in parentheses indicate the numbers of insects tested. $P$-values were calculated by Welch's $t$-test for duration of development and $t$-test for length of adult hind tibia.

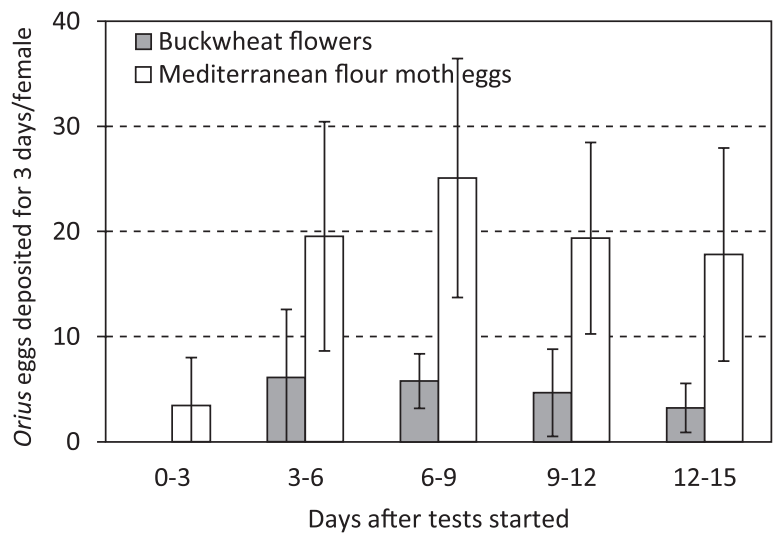

Fig. 2. The numbers of eggs deposited by Orius strigicollis females fed on buckwheat flowers or Mediterranean flour moth eggs. Bars and vertical lines show means and standard deviations, respectively.

Rijn, 2005). ヒメハナカメムシ類は，アザミウマ類や アブラムシ類, チョウ目昆虫の卵などの小動物を主な䬶 としているが，花粉や蜜，液汁など植物由来の物質も摂 食する (Pumariño et al., 2012). タイリクヒメハナカメ ムシ雌成虫に各種植物の花や葉を与えて飼育を行った 今回の試験では，フレンチマリーゴールドを除く 9 種 類の植物において，花を与えられた個体の生存期間が 同植物の葉を与えられた個体と比べて有意に長くなっ た（Fig. 1)。これは，本種成虫が花から花粉や蜜などを 餌として摂取することによって長く生存できた可能性が 考えられる。本試験で供試した植物の中でも，コリアン ダー，スィートアリッサム，スカエボラ，ソバ，ディ ル，バーベナ，ホーリーバジルの花は，タイリクヒメハ ナカメムシ雌成虫の生存期間を増加させる効果が非常 に高く，平均で約40日以上生存した（Fig. 1). Pumariño et al.（2012）は，ヒメハナカメムシ類の一種 Orius insidious Say の成虫に花の付いたソバ，スィートアリッ サムを与えた結果，花を摂食できない状態に処理した同 植物を与えた場合に比べて, 生存率や生存期間が増加し
たことを示している．特にソバの花は蜜を多く生産し， 多くの天敵を誘引することで知られている（Sustainable Agriculture Network, 1998). そのため, 本試験で供試 した 10 種の植物のうち，開花した状態のソバを初め，コ リアンダーやスィートアリッサム, スカエボラ, ディル, バーベナは，野外に生息するタイリクヒメハナカメムシ 成虫の餌資源となり，生存に有意に作用する可能性が考 えられる。

次に，ソバの花がタイリクヒメハナカメムシ幼虫の発 育や雌成虫の産卵に与える影響を調査し，ソバにおける 本種個体群の増殖の可能性を明らかにした。 その結果, 餌としてソバの花を与えられたタイリクヒメハナカメム シ幼虫は, 半数以上の個体が成虫まで発育することがで きたが，その生存率は慨としてスジコナマダラメイガ卵 を与えられた個体よりも有意に低く, 羽化成虫の体サ イズも小さくなった（Table 1). また，ソバの花を与え られたタイリクヒメハナカメムシ雌成虫の産卵数は，ス ジコナマダラメイガ卵を与えられた個体よりも有意に少 なくなった (Fig. 2). 他のヒメハナカメムシ類の Orius albidipennis (Reuter) やOrius laevigatus (Fieber) にお いても, 飭として花粉荷（ミツバチが採集した各種植物 の花粉のかたまり）を与えた個体は，スジコナマダラメ イガ卵を与えた個体と比べて, 幼虫の羽化率や成虫の 産卵数が減少することが知られている（Coccuza et al., 1997 ; Vacante et al., 1997). したがって, ソバの花は, タイリクヒメハナカメムシの餌資源として成虫の寿命を 延ばす効果はあるものの，幼虫の発育や雌成虫の産卵に 必要な栄養素が少なく, そのため, ソバはおもにタイリ クヒメハナカメムシ個体群の一時的な保護場所として機 能する可能性が示唆された。

井村・神川 (2012) は, 野外に定植したフレンチマリー ゴールドでヒメハナカメムシ類の継続的な発生を認めて おり，その要因として，フレンチマリーゴールドで䬣昆 虫のコスモスアザミウマ Microcephalothrips abdominalis 
（Crawford）が増加したことを挙げている。，一方，本試 験では, フレンチマリーゴールドの花を与えられたタイ リクヒメハナカメムシ雌成虫の生存期間は，供試した 10 種類の植物の中で最も短く, 成虫に対する延命効果は低 かった（Fig. 1). したがって，タイリクヒメハナカメム シの天敵温存植物となる植物には, ソバのような植物自 体が本種の餌資源を供給するものと，フレンチマリー ゴールドのように本種の餌昆虫を定着, 増加させるもの があるものと考えられる。

本研究では, ソバが野外に生息するタイリクヒメハナ カメムシ個体群の天敵温存植物として機能する可能性が 示唆された。しかし，実際の露地ほ場でソバなどの天敵 温存植物によってタイリクヒメハナカメムシの保護や捕 食活動の強化を実現するためには，作物上で害虫が発生 する時期に同調して天敵温存植物が開花している必要が あり，天敵温存植物の栽培特性などは今後の課題と考元 られる。

\section{摘 要}

害虫アザミウマ類の捕食性天敵であるタイリクヒメハ ナカメムシに，コリアンダー，シロツメクサ，スィート アリッサム，スカエボラ，ソバ，ディル，バーベナ，八 ゼリソウ，ホーリーバジル，マリーゴールドの花もしく は葉を与えて飼育し, 生存期間の比較を行った. フレン チマリーゴールドを除く 9 種類の植物において，花を与 えられた個体は同植物の葉を与えられた個体よりも長く 生存できた。特に, コリアンダー, スィートアリッサム, スカエボラ, ソバ, ディル，ホーリーバジルの花では, 生存期間が葉の場合の 4 倍以上長くなった。 タイリクヒ メハナカメムシ幼虫にソバの花を与えて飼育した場合, 成虫までに発育できた個体は，スジコナマダラメイガ卵 を与えた個体より少なく，また，成虫まで発育した個体 の後脚脛節長もスジコナマダラメイガ卵で発育した個体
より短くなった，さらに，雌成虫にソバの花を与えた場 合の産卵数も, スジコナマダラメイガ卵を与えた個体の 産卵数より少なかった.

\section{引用文献}

Cocuzza, G. E., P. De Clercq, M. Van de Veire, A. De Cock, D. Degheele and V. Vacante (1997) Entomol. Exp. Appl. 82: 101-104.

Eubanks, M. D. and J. D. Styrsky (2005) Effects of plant feeding on the performance of omnivorous "predators". In: PlantProvided Food for Carnivorous Insects: a protective mutualism and its applications (Wäckers, F. L., P. C. J. van Rijn and J. Bruin eds.). Cambridge University Press, New York, pp. 148-177.

Hinomoto, N., T. Higaki and T. Noda (2009) Appl. Entomol. Zool. 44: $635-642$

井村岳男・神川 論（2012）関西病虫研報 54:163-165.

Landis, D. A., S. D. Wratten and G. M. Gurr (2000) Annu. Rev. Entomol. 45: 175-201.

大野和朗（2012）バイオコントロール 16(1) : 13-17.

Pumariño, L., O. Alomar and J. G. Lundgren (2012) Entomol. Exp. Appl. 145: 181-190.

Sustainable Agriculture Network (1998) Buckwheat. In: Managing cover crops profitably, 2nd edn. (Sustainable Agriculture Network ed). Beltsville, MD., pp. 77-79.

Vacante, V., G. E. Cocuzza, P. De Clercq, M. Van de Veire and L. Tirry (1997) Entomophaga 42: 493-498.

Wäckers, F. L., P. C. J. van Rijn (2005) Food for protection: an introduction. In: Plant-Provided Food for Carnivorous Insects: a protective mutualism and its applications (Wäckers, F. L., P. C. J. van Rijn and J. Bruin eds.). Cambridge University Press, New York, pp. 1-14.

安永智秀（2001）ハナカメムシ科. 日本原色カメムシ図鑑 第 2 巻（安永智秀・高井幹夫 - 川澤哲夫編）。全国農村教育 協会, 東京. 350 pp. 278-303. 